\section{Recommendations}

(1) There appears to be an absence of a panEuropean body which could begin to look at the problems of mutual recognition and standardisation of psychiatric training. There is a clear need for discussion in an open forum to look at this issue; a possible body could be the European association of monospecialists. The Committee on Medical Training to the EEC, which provides agreed advice to the European Commission, should be consulted.

We would argue that the College needs to take a pro-active role rather than a passive one in these developments, since it would appear that other bodies are less well placed to preserve the high standards of training of the Royal College of Psy- chiatrists, and a dilution in the quality and quantity of training opportunities could occur.

The College is urged to actively pursue funding from the European Commission or other suitable bodies to facilitate such an organisation.

(2) The CTC should be an active participant in any European College activities.

(3) The College is urged to actively gather a data base on training of psychiatrists in the EC, both of official statements of policy as well as exploration of the actuality on the ground.

Michael VAN BeINUM MARTIN TURNER

Approved by Executive and

Collegiate Trainees' Committee

Finance Committee, October 1990.

\title{
ANNIVERSARY BALL
}

As part of the celebrations to commemorate the 150th Anniversary of its origins The Royal College of Psychiatrists is holding an

\section{ANNIVERSARY BALL}

at

THE NATURAL HISTORY MUSEUM SOUTH KENSINGTON, LONDON

Tuesday 22 October 1991

7.00 for 7.30

Come and dance round the dinosaur to the music of

THE DARK BLUES

The price of your ticket also includes aperitifs, a splendid dinner

and wine

TICKETS

There is a reduced price for tickets booked before 1 September:

Tickets booked before 1 September: $£ 70$

Tickets booked after 1 September: $£ 75$

Tables of eight booked before 1 September: $£ 520$

Tables of eight booked after 1 September: $£ 560$

Please apply to Christine Gear for application forms

071-235 2351, Ext. 131 